\title{
Kirjasto parantaa tutkitun tiedon
} saavutettavuutta

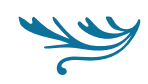

Tutkimustiedolle on kirjastoissa kysyntää, mutta mieluummin asiakas tarttuu populaariin tiedelehteen kuin tiedeyhteisölle suunnattuun tutkimusjulkaisuun.

POPULAARIT TIEDELEHDET ovat yleisten kirjastojen suosituimpia aineistoja. Tiede, Tieteen Kuvalehti, viime vuosina lisääntyneet historiaan keskittyneet lehdet ja koko repertuaari kuluvat erityisesti miesten käytössä. Kirjastoille ne ovat siten myös tasaarvokysymys.

Tiedelehtien asema kirjastoissa on vaikea horjuttaa. Jos on varaa tilata vain kymmenen lehteä, joukossa on varmasti Tiede tai muu vastaava yleislehti. Tiedelehtien tarjoaminen vastaa suoraan kirjastojen olemassaolon tarkoitusta: vuoden alusta voimaan tulleessa uudessa kirjastolaissa yhdeksi yleisen kirjaston tehtäväksi todetaan "pääsyn tarjoaminen aineistoihin, tietoon ja kulttuurisisältöihin".

Kirjastot yhdistetään turhan usein pelkästään kaunokirjallisuuteen. Tosiasiassa esimerkiksi aikuisten kirjakokoelmista reippaasti yli puolet on tietokirjoja.
Tutkijoille tarkoitetut tiedelehdet sen sijaan eivät yleisissä kirjastoissa menesty. Akateemiset ammatissa toimivat tuntuvat tilaavan ne itselleen kotiin, mikäli niitä seuraavat. Populaarit tiedelehdet päihittävät kuivan asialliset tutkimusjulkaisut, ja niiden tarjonta tuntuu vastaavan kysyntään varsin kattavasti.

Värikkäät, verkkojulkaisemisesta mallia ottavat lehdet pystyvät satsaamaan tiedon esittämistapoihin eri tavalla kuin tutkimusjulkaisut. Lukijat haluavat selkeän tekstin lisäksi kuvituksia sekä informatiivisia ja hauskoja graafeja. Siihen heitä ovat kasvattaneet myös sanomalehdet, jotka ovat Helsingin Sanomat kärkenään alkaneet panostaa tiedejulkaisemiseen.

Tiedelehtien suosio näkyy myös kirjastojen poistomyynneissä: ylimääräisiksi jääneet tiedelehtien 
LUKIJAT HALUAVAT

SELKEÄN TEKSTIN

\section{LIS ÄKSI KUVITUKSIA.}

numerot myydään vuorenvarmasti. Niiden käyttöikä on toisin sanoen pitkä.

Markkinoille on vasta tullut uusi lasten tiedelehti JunioriTieto, mutta sillä lienee tyypillinen pienen kielialueen ongelma: pysyykö julkaisu pystyssä, kun levikki jää väistämättä pieneksi. Kirjastoille tällainen aineisto on erittäin tervetullutta, koska lasten tietoaineistoista on jatkuva pula. Samalla lasten tiedelehdillä kasvatetaan yleisöä aikuisten tiedejournalismille.

Tietokirjallisuus on kirjastoissa yleisesti ottaen noususuunnassa. On perustettu tietokirjalukupiirejä, ja tietokirjallisuutta vinkataan aiempaa enemmän. Ristiriitoja herättävistä aiheista, kuten maahanmuutosta tai ilmastonmuutoksesta, luetaan ja lainataan paljon. Tutkijoiden kannattaa olla tietoisia tästä kiinnostuksesta - ja ottaa vakavasti tutkimustulostensa yleistajuistaminen.

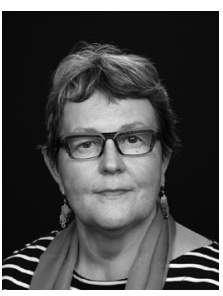

TUULA HAAVISTO

YTM, kirjastotoimen johtaja, kulttuurijohtaja Helsingin kaupunki 